\title{
Influence of Seaweed Saps on Germination, Growth and Yield of Hybrid Maize under Cauvery Command of Karnataka, India
}

\author{
Shamirkhan Dilavarnaik ${ }^{1}$, P.K. Basavaraja ${ }^{1}$, N.D. Yogendra ${ }^{2 *}$ and Arup Ghosh ${ }^{3}$ \\ ${ }^{1}$ AICRP on STCR, Department of Soil Science and Agricultural Chemistry, UAS, GKVK, \\ Bengaluru - 560 065, Karnataka, India \\ ${ }^{2}$ CSIR-Central Institute of Medicinal and Aromatic Plants, Research Centre, Bengaluru-560065, \\ Karnataka, India \\ ${ }^{3}$ CSIR-Central Salt and Marine Chemical Research Institute, Bhavnagar, Gujarat, India \\ *Corresponding author
}

\section{A B S T R A C T}

A study was conducted to determine the influence of seaweed saps [Gracilaria edulis (G sap) and Kappaphycus alvarezii (K sap) on germination, growth and Seedling Vigor Index

Keywords (SVI) under laboratory conditions followed by a field experiment to examine its foliar application on growth and yield of hybrid maize. Bioassay results revealed that soaking maize seeds in various concentrations from $5 \%$ to $15 \%$ either with $\mathrm{G}$ or $\mathrm{K}$ sap significantly increased the germination percentage $(96.67 \%)$ at $5 \%$ level. However, higher shoot length

Germination,

Maize, Growth and Yield, Seaweed sap. $(7.66$ and $8.67 \mathrm{~cm})$, SVI (3410 and 3661) at $7^{\text {th }}$ and $15^{\text {th }}$ days and dry weight of seedlings $(0.92 \mathrm{~g})$ were recorded in $15 \% \mathrm{~K}$ sap soaked seeds. Field experiment involved in soaking of

Article Info

Accepted:

17 July 2017

Available Online:

10 September 2017 maize seeds in seaweed saps followed by foliar application at different intervals. Results revealed that application of seaweed sap for maize crop with $G$ or $K$ saps at varied concentration, significantly increased cob length $(17.63 \mathrm{~cm})$, number of grains $(568.33 \mathrm{~g})$ and grain weight $\mathrm{cob}^{-1}(56.22 \mathrm{~g})$, test weight $(33.67 \mathrm{~g})$, grain and stover yield (4377.10 and $5764.31 \mathrm{~kg} \mathrm{ha}^{-1}$ respectively), were recorded when seeds were treated with $15 \% \mathrm{G}$ sap along with $10 \% \mathrm{G}$ sap spray at 20,40 and 70 days after sowing. This study clearly indicated the benefit of seaweed sap application to maize crop particularly, $15 \% \mathrm{G}$ sap seed soaking followed by $\mathrm{G}$ sap spray in increasing the maize yield.

\section{Introduction}

Seaweeds are one of the most important marine resources of the world. Seaweed extracts (saps) have been marketed for several years as fertilizer additives and beneficial results from their use have been reported (Booth, 1965). Different forms of seaweed preparation such as LSF (Liquid Seaweed Fertilizers), SLF (Seaweed Liquid Fertilizers), LF (Liquid Fertilizers) are either whole or finally chopped powered algal manure have been used and all of them have been reported to produce beneficial effects on cereals, pulses and horticultural crops. In addition to small quantity of plant nutrients, seaweeds contain many trace elements, minerals, protein, iodine, bromine, vitamins and many bioactive substances. Chemical analysis of seaweeds and their extracts have revealed the presence of a wide variety of plant growth regulators such as auxins and cytokinins in 
varying amounts (Zhang and Ervin, 2008). Promising increased crop yield, nutrient uptake, resistance to frost and stress, improved seed germination, reduced incidence of fungal and insect attack, elevated resistance to biotic and abiotic stress, and enhanced postharvest shelf-life of perishable products have been resulted by application of SLF, (Norrie and Keathley, 2006). Hence, marine algae, particularly seaweeds have a vital role to play in agriculture, especially in the third world country where irrational use of chemical fertilizer and pesticides is a cause of concern.

Seaweeds are cheap source of minerals and trace elements. Seaweed manure has been found superior to farm yard manure. The high amount of water soluble potash, other minerals and trace elements present in seaweeds are readily absorbed by plants and control mineral deficiency diseases. The carbohydrates and other organic matter present in the marine algae alter the nature of soil and improve the moisture retaining capacity. The liquid seaweed fertilizer obtained from seaweed extract is used as foliar spray for inducing faster growth and yield in leafy and fleshy vegetables, fruits, orchards and horticultural plants. Numerous studies have revealed a wide range of beneficial effects of seaweed extract applications on plants. The seaweed concentrates are applied to crops as foliar sprays, soil drenches or root dips. Seaweed concentrates are effective biostimulant in many crops including vegetables, trees, flowering plants and grain crops (Stirk et al., 2004). Method of fertilizer application plays a vital role in achieving higher yield of the crops. Foliar application of mineral nutrients offers a quicker method of supplying nutrients to higher plants than methods involving soil application. In this context the present work was undertaken to study the influence of different concentrations of seaweed saps in bioassays techniques and its influence on growth and yield of hybrid maize under field study.

\section{Materials and Methods}

\section{Laboratory experiment}

To study the influence of different concentrations of seaweed saps on germination using bioassay techniques on hybrid maize, a laboratory experiment was conducted at STCR laboratory, UAS, GKVK, with varied concentrations of Kappaphycus alvarezii (K sap) and Gracilaria edulis ( $\mathrm{G}$ sap). Ten disinfected maize seeds were soaked in each seaweed saps separately with different concentrations viz., $0,2.5 \%, 5 \%$, $10 \%, 15 \%$ and $20 \%$ for 12 hours. The same treatments were replicated thrice. These treated seeds were covered with germination papers and placed in a controlledenvironmental growth chamber at $25^{\circ} \mathrm{C}$ temperature with 90 per cent relative humidity. These seeds were moistened with distilled water every alternate days and distilled water soaked seeds were used as control.

After 3 days, germination papers were opened and numbers of seeds germinated were recorded and final germination percentage was determined after 7 days for each treatment. After $7^{\text {th }}$ and $15^{\text {th }}$ days, shoot length and root length of germinated seedlings in each treatment were measured. Seedling vigor index was computed as per Abdul Baki and Anderson method (1973). Fresh weight of seedlings were recorded immediately after recording shoot and root length at $7^{\text {th }}$ and $15^{\text {th }}$ days of incubation and dry weight was determined at $15^{\text {th }}$ day after oven drying the seedlings at $85 \pm 1{ }^{0} \mathrm{C}$ for $24 \mathrm{hr}$. All these parameters were statistically analyzed by standard procedure (Panse and Sukhatme, 1967). 


\section{Field experiment}

The field study was conducted at Zonal Agricultural Research Station, Vishweshwaraiah Canal Farm, Mandya, during Kharif, 2013. It lies between $12^{\circ} 32^{\prime} \mathrm{N}$ latitude and $76^{\circ} 53^{\prime}$, E, which comes under southern dry zone (zone 6) of Karnataka. longitude and 695 meters above mean sea level. The experimental soil is red sandy clay loam with neutral $\mathrm{pH}$ (7.60) with normal electrical conductivity $\left(0.167 \mathrm{dS} \mathrm{m}^{-1}\right.$ at $\left.25^{\circ} \mathrm{C}\right)$. The organic carbon content was medium (5.1 $\left.\mathrm{g} \mathrm{kg}^{-1}\right)$. The available nitrogen content of the soil was low (265.07 $\mathrm{kg} \mathrm{N} \mathrm{ha}^{-1}$ ), phosphorus was high (59.31 kg $\mathrm{P}_{2} \mathrm{O}_{5} \mathrm{ha}^{-1}$ ) and potash was medium (140.0 kg K $2 \mathrm{O} \mathrm{ha}^{-1}$ ). The experiment was out laid in RCBD replicated thrice with eleven treatments. (viz; $\mathrm{T}_{1}$ : Control (3 times water spray), $\mathrm{T}_{2}$ : Seed treatment with $15 \% \mathrm{G}^{*}$ sap (3 times water spray), $\mathrm{T}_{3}$ : Seed treatment with $15 \% \mathrm{~K}^{*}$ sap (3 times water spray), $\mathrm{T}_{4}$ : $5 \% \mathrm{G}$ sap spray (3 times spray), $\mathrm{T}_{5}: 10 \% \mathrm{G}$ sap spray (3 times spray), $\mathrm{T}_{6}: 10 \% \mathrm{~K}$ sap spray (3 times spray), $\mathrm{T}_{7}: 15 \% \mathrm{~K}$ sap spray (3 times spray), $\mathrm{T}_{8}$ : Seed treatment with $15 \% \mathrm{G}$ sap $+\mathrm{T}_{4}, \mathrm{~T}_{9}$ : Seed treatment with $15 \% \mathrm{G}$ sap $+\mathrm{T}_{5}, \mathrm{~T}_{10}$ : Seed treatment with $15 \% \mathrm{~K}$ sap + $\mathrm{T}_{6}, \mathrm{~T}_{11}$ : Seed treatment with $15 \% \mathrm{~K}$ sap $+\mathrm{T}_{7}$ ). The hybrid maize (Hema NAH 1137) was sown on $2^{\text {nd }}$ August 2014, after soaking the seeds in water or respective seaweed saps as per the treatments with a spacing $60 \mathrm{~cm} \mathrm{X} 30$ $\mathrm{cm}$ after application of recommended dose of fertilizers (RDF: $150: 75: 40$ NPK kg ha-1, $10 \mathrm{~kg} \mathrm{ha}^{-1} \mathrm{ZnSO}_{4}$ and $10 \mathrm{t} \mathrm{ha}^{-1}$ FYM) uniformely for all the treatments including control. Irrigation was given 6-8 days interval during the crop growth period. Foliar appliaction of seaweed sap was fixed at 20, 40 and 70 days after sowing (DAS) (G and K sap spray concentration were fixed based on the earlier field experimental results).

During harvest of the crop observations were recorded on plant height, number of leaves per plant cob length, number of grains per cob, grain weight per cob, test weight, grain and stover yield. Soil samples drawn before initiation of the experiment and after harvest were subjected for physico-chemical analysis. All these crop and soil parameters were statistically analyzed by following Fisher's method of analysis of variance as outlined by Panse and Sukhatme (1967). The 'F' test was applied at $\mathrm{P}=0.05$ levels and significant levels established. The interpretation of data was done on the critical difference (CD) values calculated at $\mathrm{P}=0.05$.

\section{Results and Discussion}

\section{Laboratory experiment}

\section{Germination percentage}

Bioassay study indicated a significantly highest germination of $96.67 \%$ in seeds soaked with $5 \%$ to $15 \%$ concentration of either $\mathrm{G}$ or $\mathrm{K}$ sap. But, when the concentration is reduced to $2.5 \%$ or increased to $20 \%$, significant reduction in the germination was noticed (Fig. 1). The increased germination percentage at lower concentrations could be due to presence of growth promoting substances such as indole3 -acetic acid (IAA) and indole butyric acid (IBA), gibberellins $\mathrm{A}$ and $\mathrm{B}$, cytokinins, micronutrients ( $\mathrm{Fe}, \mathrm{Cu}, \mathrm{Zn}, \mathrm{Co}, \mathrm{Mo}, \mathrm{Mn}$ and $\mathrm{Ni}$ ), vitamins and amino acids as reported in the past (Challen and Hemingway, 1966). The results of the present study coincide with those of earlier studies made in Cajanus cajan (Mohan et al., 1994), Zea mays, Elusine coracona and Pennisetum typhoides (Rajkumar Immanuel and Subramanian, 1999). Reduction in germination percentage was noticed at higher concentrations of $\mathrm{G}$ or $\mathrm{K}$ seaweed sap. This might be due to inhibition of germination by the high salts concentration of seaweed saps. Salt stress induced inhibition of seed germination, seedling growth and metabolic processes were reported in maize (Azevedo et al., 2004) and 
wheat (Brini et al., 2009), which corroborated the results of the present study. These results are in agreement with the findings of Gaurav Kumar and Dinabandhu Sahoo (2011).

\section{Shoot length, root length and seedling vigour index (SVI)}

The application of seaweed extract at different concentrations enhanced shoot length, root length and seedling vigour index. Higher shoot length, root length and vigour index was noticed when seeds were soaked in $15 \% \mathrm{G}$ or $15 \% \mathrm{~K}$ sap.

Beyond this concentration, these variables decreased substantially (Figs. 2 and 3). The higher SVI at $15 \%$ of either K or G sap was mainly due to higher germination percentage and seedling length.

The results are in conformity with the findings of Gaurav Kumar and Dinabandhu Sahoo (2011), who reported the increased germination percentage, shoot length and root length of wheat with $20 \%$ concentration of Sargassum wightii, whereas higher concentration beyond $20 \%$ decreased these parameters. Gollan and Wright (2006) concluded that the increase in shoot characteristics due to auxins content in seaweed extracts have an effective role in cell division and enlargement; which leads to increase the shoot growth, leaf area and plant dry weight.

\section{Seedling fresh and dry weight}

Fresh weight of seedlings differed significantly due to seed dipping with various concentrations of seaweed saps. Highest fresh weight of seedlings was recorded in seeds soaked at $15 \% \mathrm{G}$ sap (3.0 g) and lowest fresh weight $(2.41 \mathrm{~g})$ of seedlings was recorded in control. The K sap also followed the trend of G sap where higher fresh weight of seedlings was recorded with seeds soaked at $15 \% \mathrm{~K}$ sap and lowest fresh weight of seedlings was in $2.5 \% \mathrm{~K}$ sap seed soaking (Fig. 4). But, it was higher than the control. Kalaivanan and Venkatesalu (2012) reported increase in shoot length, root length, fresh weight and dry weight at $10 \%$ concentration of $S$. myriocystum treated seedlings. Further increase in the seaweed extract concentration reduced the fresh weight and dry weight of Vigna mungo. The increased fresh and dry weight in the present study upto 15\% concentration of $\mathrm{G}$ or $\mathrm{K}$ sap was due to higher shoot and root length in these treatments. But, application of seaweed saps at higher concentration reduced the fresh and dry weight of maize seedlings, similar to the study of Kalaivanan and Venkatesalu (2012) on Vigna mungo (L). Beneficial effects observed in various plant growth bioassays have lead to speculation that SWCs contain plant growth-regulatory substances. Furthermore, the wide range of growth responses induced by seaweed extracts implies the presence of more than one group of plant growth promoting substances or hormones (Crouch and Van Staden, 1993).

\section{Field experiment}

The different seaweed saps of various concentration and different methods of application resulted in positive and significant influence on growth and yield parameters of maize crop.

The application of seaweed saps did not increase the plant height and number of leaves significantly among the different methods followed for treating maize crop with $\mathrm{G}$ or $\mathrm{K}$ saps (Table 1). However, numerically higher values were recorded in seed treatment with $15 \%$ G sap along with $10 \%$ G sap spray followed by seed treatment with $15 \% \mathrm{~K}$ sap along with $15 \% \mathrm{~K}$ sap spray and lower values were recorded in control. 
Table.1 Influence of seaweed saps on growth and yield parameters of hybrid maize

\begin{tabular}{|c|c|c|c|c|c|c|c|c|c|c|c|c|}
\hline \multirow{3}{*}{ Treatments } & \multicolumn{3}{|c|}{ Plant height $(\mathrm{cm})$} & \multicolumn{3}{|c|}{ Number of leaves } & \multirow{2}{*}{$\begin{array}{c}\text { Cob } \\
\text { length } \\
(\mathrm{cm}) \\
\end{array}$} & \multirow{2}{*}{$\begin{array}{r}\text { No. of } \\
\text { grains } \\
\text { per cob }\end{array}$} & \multirow{2}{*}{$\begin{array}{l}\text { Grain } \\
\text { wt per } \\
\text { cob }(g)\end{array}$} & \multirow{3}{*}{$\begin{array}{c}\text { Test } \\
\text { weight (g) }\end{array}$} & \multirow{2}{*}{$\begin{array}{c}\text { Grain } \\
\text { yield }\end{array}$} & \multirow{2}{*}{$\begin{array}{c}\text { Stover } \\
\text { yield }\end{array}$} \\
\hline & & DAS & & & DAS & & & & & & & \\
\hline & 20 & 40 & 70 & 20 & 40 & 70 & \multicolumn{3}{|c|}{ At harvest } & & \multicolumn{2}{|c|}{$\left(\mathrm{kg} \mathrm{ha}^{-1}\right)$} \\
\hline $\mathrm{T}_{1}:$ Control (3 times water spray) & 20.00 & 72.40 & 160.73 & 4.87 & 8.93 & 11.47 & 16.17 & 377.67 & 37.69 & 30.33 & 3333.33 & 4579.80 \\
\hline $\begin{array}{l}\mathrm{T}_{2}: \text { Seed treatment with } 15 \% \text { G sap } \\
\text { (3 times water spray) }\end{array}$ & 20.00 & 78.93 & 173.27 & 5.27 & 9.60 & 12.03 & 17.27 & 483.33 & 48.23 & 32.67 & 4006.73 & 5498.32 \\
\hline $\begin{array}{l}\mathrm{T}_{3}: \text { Seed treatment with } 15 \% \mathrm{~K} \text { sap } \\
\text { (3 times water spray) }\end{array}$ & 20.30 & 73.47 & 163.47 & 5.13 & 9.40 & 12.00 & 16.80 & 451.67 & 42.28 & 32.10 & 3771.04 & 5158.25 \\
\hline $\mathrm{T}_{4}: 5 \%$ G sap spray & 20.57 & 73.47 & 163.47 & 5.13 & 9.40 & 11.93 & 16.70 & 430.33 & 42.04 & 30.83 & 3602.69 & 5101.01 \\
\hline $\mathrm{T}_{5}: 10 \% \mathrm{G}$ sap spray & 20.43 & 74.93 & 166.93 & 5.13 & 9.53 & 12.00 & 17.07 & 453.67 & 44.13 & 31.83 & 3804.71 & 5306.40 \\
\hline $\mathrm{T}_{6}: 10 \% \mathrm{~K}$ sap spray & 20.23 & 73.33 & 161.67 & 5.00 & 9.13 & 12.00 & 16.60 & 426.00 & 41.86 & 30.71 & 3585.86 & 5097.64 \\
\hline $\mathrm{T}_{7}: 15 \% \mathrm{~K}$ sap spray & 20.53 & 80.13 & 169.67 & 5.13 & 9.53 & 11.87 & 17.10 & 456.33 & 44.40 & 32.00 & 3872.05 & 5417.51 \\
\hline $\mathrm{T}_{8}:$ Seed treatment with $15 \% \mathrm{G}$ sap $+\mathrm{T} 4$ & 20.97 & 82.40 & 176.40 & 5.30 & 9.60 & 12.06 & 17.53 & 514.00 & 53.48 & 32.00 & 4040.40 & 5609.43 \\
\hline $\mathrm{T}_{9}:$ Seed treatment with $15 \% \mathrm{G}$ sap $+\mathrm{T} 5$ & 21.36 & 85.48 & 178.40 & 5.33 & 9.64 & 12.06 & 17.63 & 568.33 & 56.22 & 33.67 & 4377.10 & 5764.31 \\
\hline $\begin{array}{l}\mathrm{T}_{10}: \text { Seed treatment with } 15 \% \mathrm{~K} \text { sap }+ \\
\text { T6 }\end{array}$ & 20.60 & 80.13 & 171.80 & 5.20 & 9.60 & 12.06 & 17.20 & 457.67 & 44.97 & 31.50 & 3939.39 & 5481.48 \\
\hline $\begin{array}{l}\mathrm{T}_{11}: \text { Seed treatment with } 15 \% \mathrm{~K} \text { sap }+ \\
\mathrm{T} 7\end{array}$ & 20.93 & 83.40 & 173.40 & 5.33 & 9.60 & 12.05 & 17.30 & 492.33 & 48.72 & 32.50 & 4040.40 & 5515.15 \\
\hline S.Em \pm & 0.46 & 4.72 & 8.18 & 0.15 & 0.30 & 0.21 & 0.24 & 9.23 & 0.33 & 0.94 & 255.60 & 367.16 \\
\hline C.D. (5\%) & NS & NS & NS & NS & $\mathbf{N S}$ & NS & 0.72 & 27.22 & 0.96 & 2.79 & 754.01 & 1083.11 \\
\hline
\end{tabular}


Fig.1 Influence of seaweed saps on maize seed germination

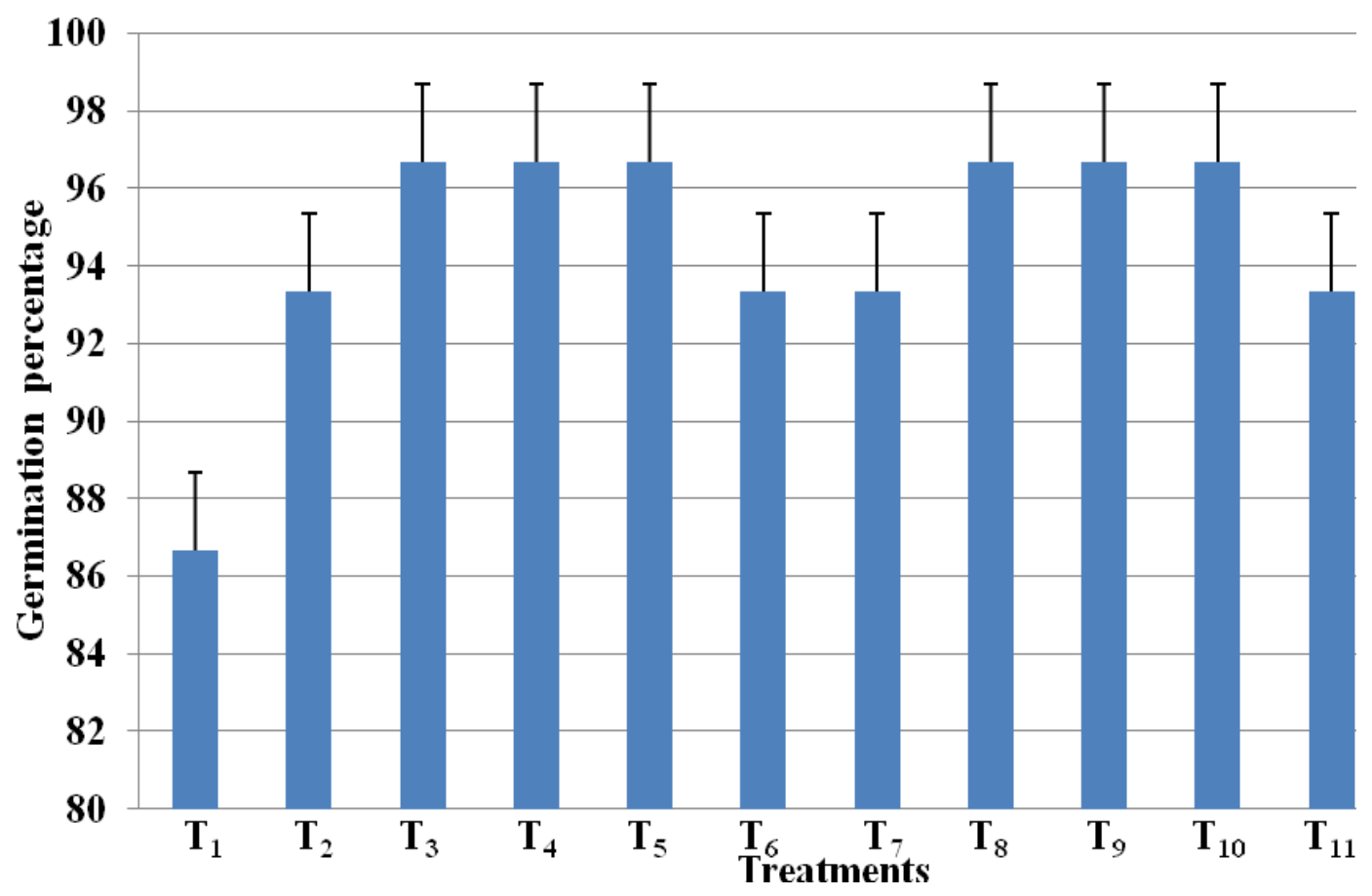

Fig.2 Influence of seaweed saps on shoot length and root length at 7 and 15 days after seed soaking

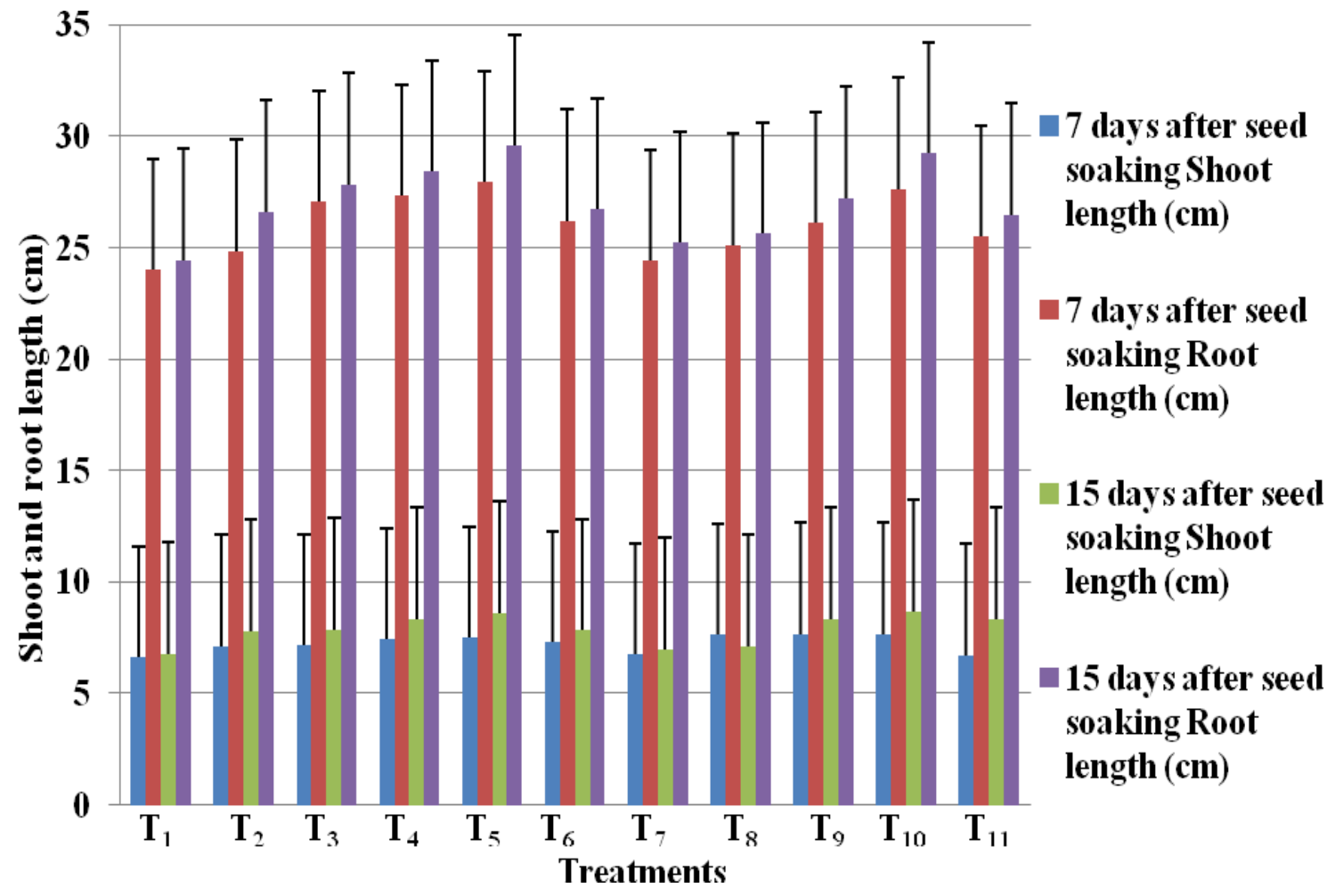


Fig.3 Influence of seaweed saps on seedling vigour index (SVI)

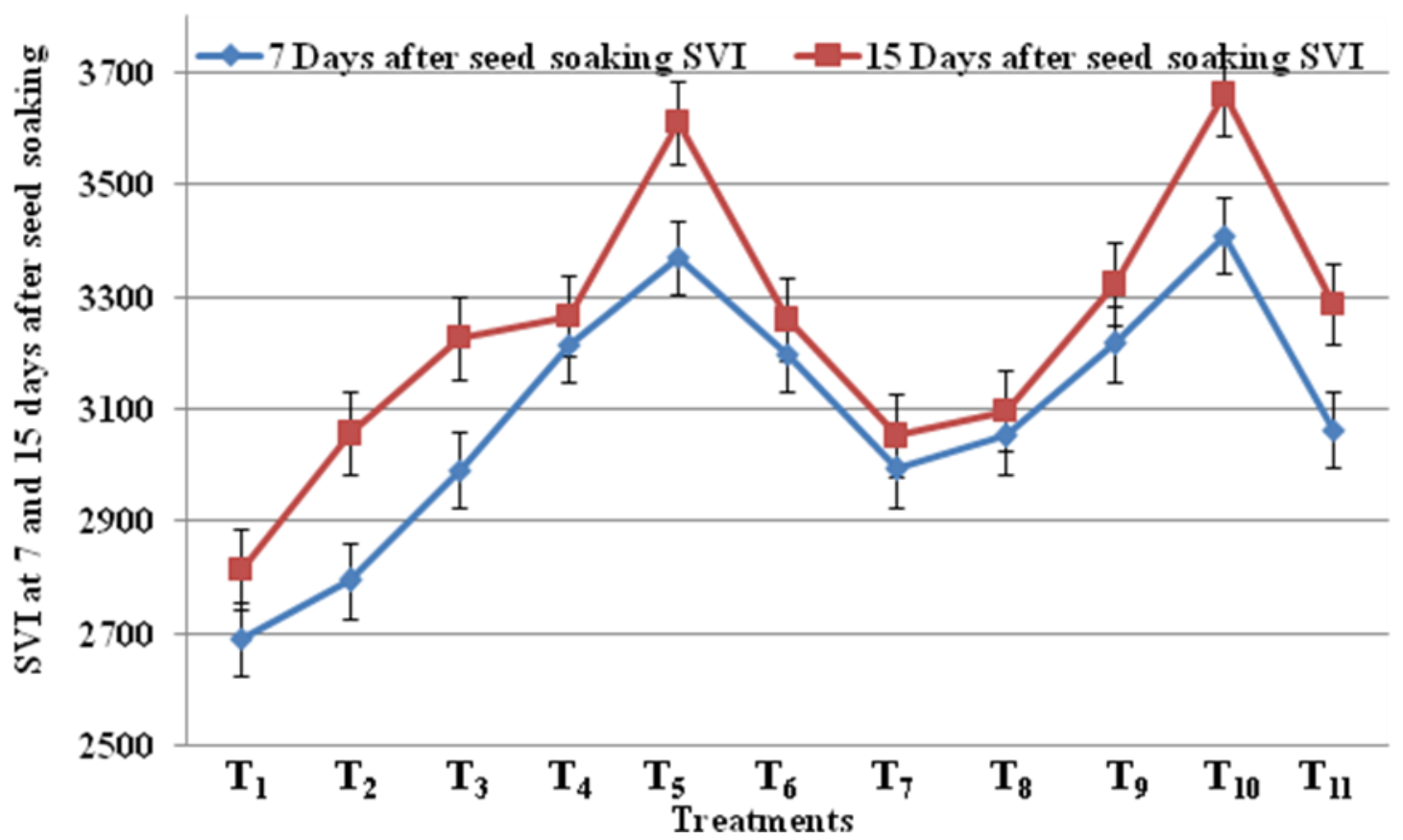

Fig.4 Influence of seaweed saps on seedling fresh weight and dry weight

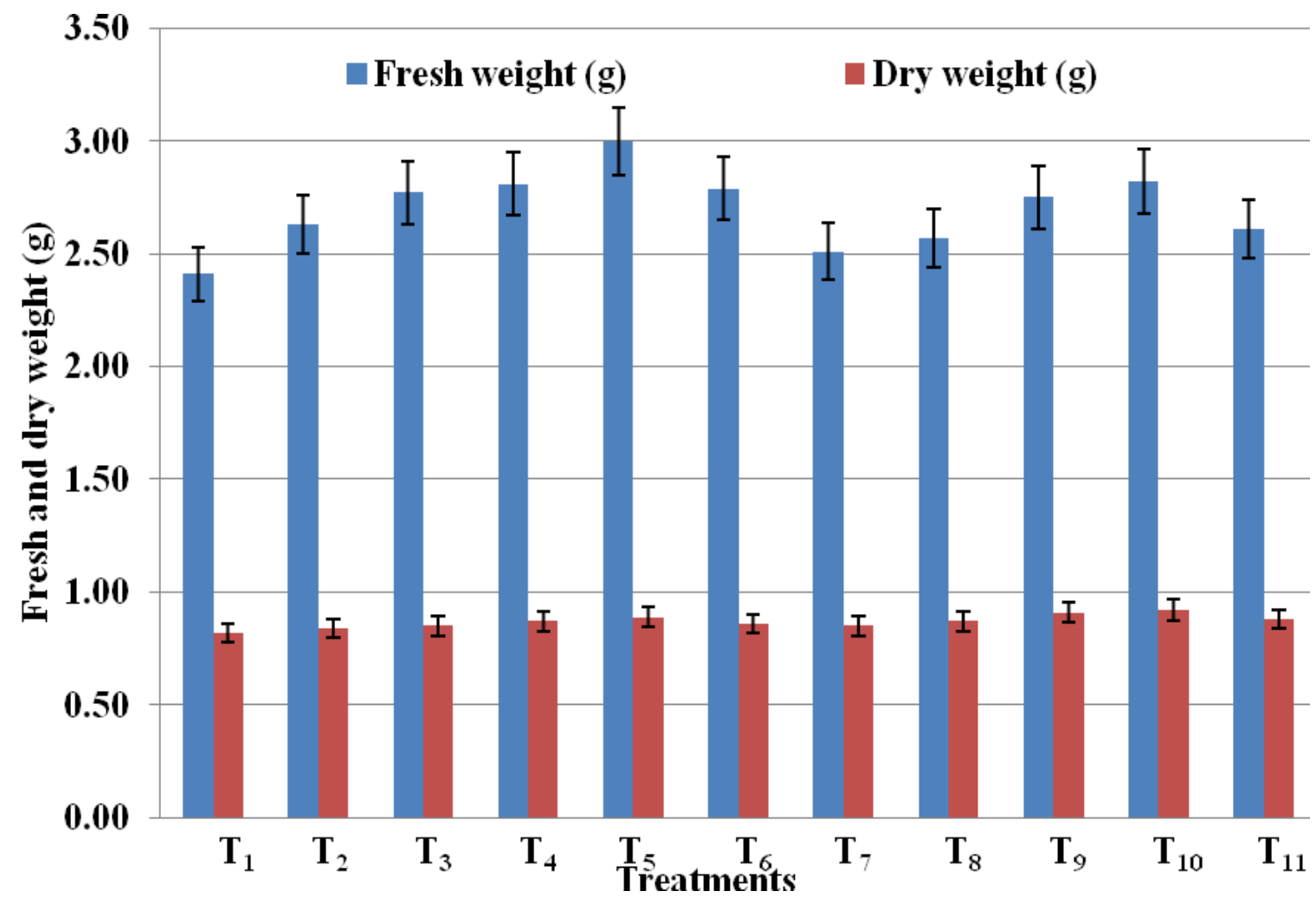


The present findings were in agreement with the findings of Kelting et al., (1998) who noticed no differences in height, stem diameter, top dry mass or root length in Acer rubrum due to different biostimulants, but they did observe significant differences in top dry mass in Crataegus phaenopyrum.

Yield and yield parameters like cob length, the number of grains per cob, grain weight per cob, test weight, grain yield and stover yield data are presented in table 1. Significantly highest cob length, the number of grains per cob, grain weight per cob and test weight (100 seed weight) were recorded in seed treatment with $15 \%$ G sap along with $10 \%$ G sap spray, whereas significantly lowest values were recorded in control. These results are in agreement with the findings of Zodape et al., (2008) who reported that seaweed extract application increased the length, diameter and yield of Ablemoschus esculentus than the control.

The grain and stover yield was significantly highest in seed treatment with $15 \% \mathrm{G}$ sap along with $10 \% \mathrm{G}$ sap spray (4377.10 and $5764.31 \mathrm{~kg} \mathrm{ha}^{-1}$ ) followed by seed treatment with $15 \% \mathrm{G}$ sap along with $5 \% \mathrm{G}$ sap spray and seed treatment with $15 \% \mathrm{~K}$ sap along with 15\% K sap spray (4040.40 and 5515.15 $\mathrm{kg} \mathrm{ha}^{-1}$ ) and the lowest yield recorded in control. The increase in grain yield in the present study was attributed to increase in cob length, number of grains per cob, grain weight per cob and 100 grain weight. In many crops yield is associated with number of flowers at maturity, as the onset and development of flowering and the number of flowers produced are linked to the developmental stage of plants. Seaweed extracts probably encourage flowering by initiating robust plant growth. Yield increases in seaweed-treated plants are also thought to be associated with the hormonal substances present in the extracts, especially cytokinins (Featonby-
Smith and Van Staden, 1984). Similarly, a substantial increase in yield was achieved in barley (Featonby-Smith and van Staden, 1987) and peppers (Arthur et al., 2003) after treatment with Kelpak. Zodape et al., (2009) reported that increased yield and yield attributes in wheat crop due to presence of some growth promoting substances such as IAA and IBM, gibberellins, cytokinins, micronutrients, vitamins and amino acids. In the present study application of seaweed extract as foliar spray at three different stages viz., vegetative, initiation of tassel and at maturity stage (20, 40 and 70 days after sowing of the crop) might have helped the crop to achieve higher grain and stover yield as compared to control.

Significant increase in stover yield of maize was noticed at seed treatment with $15 \%$ G sap along with $10 \% \mathrm{G}$ sap spray as compared to control. The results of the present study was in harmony with Gaurav Kumar and Dinabandu Sahoo (2011), who reported that lower concentration of SWE enhanced the per cent germination, growth and yield as measured by kernel number and seed dry weight. The promotive effects of seaweed application at three different steps viz., vegetative, initiation of tassel and at maturity stage (20, 40 and 70 days after sowing of the crop) in the present investigation might be due to increased root proliferation and establishment, there by plants were able to mine more nutrients even from distant places and deeper soil horizons, in balanced proportion. Besides, seaweed extract, regulated the plant bio-physiological activities which collectively resulted in maintaining higher photosynthetic activities (Singh and Chandel, 2005).

In conclusion, seaweed sap application at $15 \%$ concentration of either $\mathrm{K}$ or $\mathrm{G}$ sap significantly increased the germination, SVI, fresh and dry weight, whereas at higher 
concentration reduction in these parameters were noticed. Seed soaking in seaweed saps at $15 \% \mathrm{G}$ sap followed by three sprays of $10 \%$ $\mathrm{G}$ sap spray at 20, 40 and 70 days after sowing significantly increased the grain and straw yield of hybrid maize.

\section{References}

Abdul-Baki, A.A., and Anderson, J. A., 1973, Vigour determine of soybean seeds by multiple criteria. Crop Sci., 13:630-633.

Arthur, G.D., Stirk, W. A. and Van Steden, J. 2003. Effect of seaweed concentrates on the growth and yield of three varieties of capsicum annuum, $s$ afr $j$ bot. 69:207-211.

Azevedo Neto, A.D., J. T. Prisco, F. J. Eneas, C. F. Lacerda, J. V. Silva, P. H. A. Costa and F. E. Gomes. 2004. Effects of salt stress on plant growth, stomatal response and solute accumulation of different maize genotype. Braz. J. Plant Physiol. 6: 31-38.

Booth, E., 1965. The manufacture and properties of liquid seaweed extracts. In: Blunden, g. (ed) proceedings of the sixth international seaweed symposium, Tokyo, pp 655-662.

Brini, F., I. Amara, K. Feki, M. Hanin, H. Khoudi and K. Masmoudi. 2009. Physiological and molecular analyses of seedlings of two Tunisian durum wheat (Triticum turgidum L. sub sp. Durum [Desf.]) varieties showing contrasting tolerance to salt stress. Acta. Physiol. Plant. 31: 145- 154.

Challen, S.B., and Hemingway, J. C., 1966, Growth of higher plants in response of feeding with seaweed extracts, in Proc fifth Intl. Seaweed Symp, Halifax (Pregamon Press, Oxford), 5: 359-367.

Crouch, I.J., and Van Staden, J. 1993. Effect of seaweed concentrate from ecklonia maxima (osbeck) papenfuss on meloidogyne incognita infestation on tomato. J. Appl. Phycol. 5: 37-43.

Featonby-Smith, B.C., and Van Staden, J. 1984. Effect of seaweed concentrate and fertilizer on the growth of beta vulgaris. zpflanzenphy siol. 112:155-162.

Featonby-Smith, B.C., and Van Staden, J. 1987. Effects of seaweed concentrate on grain yield in barley. South Afri. J. Bot. 53:125-128.

Gaurav Kumar, and Dinabandhu Sahoo. 2011. Effect of seaweed liquid extract on growth and yield of triticum aestivum var. pusa gold, J. Appl. Phycol. 23: 251-255.

Gollan, J.R., and Wright, J. T. 2006. Limited grazing pressure by native herbivores on the invasive seaweed caulerpa. Taxi folia in a temperate. Australia Estuary Marine and Freshwater Res. 57 (7): 685-694.

Kalaivanan, C., and venkatesalu, V. 2012. Utilization of seaweed Sargassum myriocystum extracts as a stimulant of seedlings of Vigna mungo (L.) Hepper. Spanish J. Agri. Res. 10(2): 466-470.

Kelting, M.P., Harris Jr, Fanelli J. and Appleton, B. 1998. Biostimulants and soil amendments affect two year post transplant growth of red maple and Washington hawthorn. Hort. Sci. 33: 819-822.

Mohan, V.R., Venkataraman Kumar, V., Murugeswari R. and Muthusamy, S., 1994, Effect of crude and commercial seaweed extract on seed germination and seedling growth in Cajanus cajan L. Phykos, 33:47-51.

Norrie, J., and Keathley J. P., 2006. Benefits of Ascophyllum nodosum marine-plant extract applications to 'Thompson seedless' grape production. Acta Hortil. 727: 243-247.

Panse, V.G., and Sukhatme, P. V. 1967. Statistical methods for Agricultural workers, ICAR, New Delhi, 357-358.

Rajkumar Immanuel, S., and Subramanian, S. 
K., 1999, Effect of fresh extract and seaweed liquid fertilizer on some cereals and millets. Seaweed Res. Utiln., 21(1 and 2): 91-94.

Singh, P.K., and Chandel, A. S. 2005. Effect of bioenzyme on yield and quality of wheat (Triticum aestivum). Indian $J$. Agron. 50: 58-60.

Stirk, W.A., Arthur, G. D., Lourens, A. F., Novok, O., Strnad, M. and Van Staden, J. 2004. Changes in cytokinin and auxin concentrations in seaweed concentrates when stores at an elevated temperatures. J. Appl. Phyl. 16: 31-39.

Van Staden, J., Upfold, J. and Dewes, F. E. 1994. Effect of seaweed concentrate on growth and development of the marigold Tagetes patula. J. Appl. Phycol. 6: 427-428.
Verkleij, F.N., 1992. Seaweed extracts in agriculture and horticulture a review. Biol. Agri. Horti. 8(4): 309-324.

Zhang, X., and Ervin E. H. 2008. Impact of seaweed extract-based cytokinins and zeatin riboside on creeping bentgrass heat tolerance. Crop Sci. 48: 364-370.

Zodape, S.T., Kawarkhe, V. J., PATOLIA, J. S. AND WARADE. A. D. 2008. Effect of liquid seaweed fertilizer on yield and quality of okra (Abelmoschus esculentus L.). J. Sci.Ind. Res. 7: 1115-1117.

Zodape, S.T., Mukherjee, S., Reddy, M. P. and Chaudhary, D. R. 2009. Effect of Kappaphycus alvarezii (Doty) Doty ex silva extract on grain quality, yield and some yield components of wheat (Triticum aestivum L.), Intl. J. Plant Prod., 3 (2): 97-101.

\section{How to cite this article:}

Shamirkhan Dilavarnaik, P.K. Basavaraja, N.D. Yogendra and Arup Ghosh. 2017. Influence of Seaweed Saps on Germination, Growth and Yield of Hybrid Maize under Cauvery Command of Karnataka. Int.J.Curr.Microbiol.App.Sci. 6(9): 1047-1056. doi: https://doi.org/10.20546/ijcmas.2017.609.126 